\title{
Black flies (Diptera: Simuliidae) of Ethiopia I. On four new and three uncertain species of Simulium Latreille
}

\author{
Kiichi Uemoto, ${ }^{*}$ Kazuki OGata** and Yemane MEBRahtu*** \\ * Department of Medical Zoology, Kyoto Prefectural University of \\ Medicine, Kamigyo-ku, Kyoto 602, Japan \\ ** Japan Environmental Sanitation Center, Kawasaki 210, Japan \\ *** Central Laboratory and Research Institute, P.O. Box 1242, \\ Addis Ababa, Ethiopia
}

(Received: December 1, 1976)

\section{INTRODUCTION}

During 1969 to 1973, the surveys on the distribution of the vectors of onchocerciasis were carried out in Ethiopia by the joint support of the Central Laboratory and Research Institute, Ethiopia and the Overseas Technical Cooperation Agency, Japan.

Totally seven unrecorded species, four of them belonging to the subgenus Pomeroyellum Rubzov and the other three belonging to the subgenus Metomphalus Enderlein, were found through these surveys.

The pupae of one species belonging to Pomeroyellum might correspond with the specimen with 12 filaments which Freeman and de Meillon (1953) assigned to S. momahoni de Meillon, because the difference in the number of filaments between this and the typical form with 8 filaments was considered to be only of individual variations. However, we believe that our specimens collected from Ethiopia should be independent from $S$. momahoni, because these are clearly differentiated from the typical form of $S$. momahoni not only by the characters of male or larva, but also by the fact that both

* 上本騏一：京都府立医科大学医動物学教室（行 602 京都市上宗区河原町広小路）

**緒方一喜：日本環境衛生 センター環境生物部

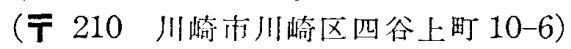

forms have never been collected together at the same places, although both of them are found in Ethiopia. In the other three species belonging to Pomeroyellum, males or both sexes have not been obtained. These appear to be new species, but the identities of them must remain uncertain until bred male adults are obtained to help in deciding the status of each species.

The three unrecorded species belonging to Metomphalus are distinct from any species described in this subgenus to date.

Regarding the descriptions of Ethiopian species, we follow the re-classification of $R$. W. Crosskey (1969).

\section{Simulium (Pomeroyellum) awashense new species}

Female. General body color brownishblack to black. Length: body $1.55-2.20 \mathrm{~mm}$, wing $1.50-1.90 \mathrm{~mm}$.

Head blackish-brown with thin greyish pollinosity, frons with long pale yellow hairs mainly on upper part. Clypeus shining, with long greyish-white hairs. Antenna 11-segmented, dark brown except basal 3 segments yellow or slightly brownish-yellow. Maxillary palpus dark blackish-brown, sensory vesicle only about one-third as long as its segment. Mandible with 22-24 inner teeth and 10-12 outer teeth; maxilla with about 13 inner teeth and 11 outer teeth. 
Thorax blackish-brown; scutum almost unicolorous but with 3 very indistinct, narrow, darker lines, sparsely clothed with pale yellow hairs except its medial part bare; scutellum with pale yellow hairs and long greyish hairs. Pleural membrane, katepisternum and postnotum all bare. Fore and mid femora yellowish-brown, with darker brown apices; hind femur darker brown except for the extreme base pale brown, with darkened band on apical fifth. Fore and mid tibiae yellowish-brown, darkened at bases and apices: hind tibiae yellowishbrown, with dark brown bands on apical fifth and subbasal fourth. Tarsi almost dark brown or brownish-black except most of hind metatarsus pale yellowish. Fore tarsi not at all enlarged, fore metatarsus nearly 8 times as long as broad; hind metatarsus narrow and parallel-sided, about 7 times as long as broad. Calcipala and pedisulcus well developed. Claws with strong basal tooth. Wings hyaline; basal section of radius haired; basal hair tufts brownish-black. Knob of haltere pale yellowish. Abdomen blackish-brown, evenly clothed with golden and blackish-brown hairs; basal fringe pale yellow. Sternites VI-VII sparsely clothed with black bristles. Spermatheca elliptic shape, with faint surface reticulation. Terminalia as in Fig. 1; ovipositor lobe rounded, with a chitinous process near its inner base and looks to be folded longitudinally at this process in ventral view. Genital fork spatulate at extreme base; its arms relatively short, narrow, slightly curved; distal end with two blunt processes projecting medially and anteriorly; anterior one of these processes heavily sclerotized. Cercus large and subquadrate in profile. Anal lobe relatively narrow and very weakly sclerotized.

Male. General body color brownish-black to black. Length : body $1.60-2.50 \mathrm{~mm}$, wing $1.50-1.85 \mathrm{~mm}$.

Generally very similar to female, with same thoracic, abdominal and leg coloring, but most of first flagellomere of antenna as usual more brownish-black; hairs of scutum as in female. Fore metatarsus as in female but outer side of hind metatarsus slightly convex in profile, its length about 6.3 times as great as maximum breadth. Genitalia as shown in Fig. 1; style about two-thirds as long as coxite, tapering and curved apically, with a single terminal spinule. Ventral plate transverse and slightly excavate laterally; body of ventral plate about twice as wide as long, with long hairs on a postero-medial, chitinous projection; postero-lateral shoulders strongly projecting, with notches on each apex. Paramere of hinged type, with one long hook and two smaller hooks arising from thin terminal part of paramere. Median sclerite narrow and rather deeply bifurcate apically. Cercus subtriangular.

Pupa. Length 2.05-2.40 mm. Respiratory organ $1.25-1.55 \mathrm{~mm}$, with 12 slender filaments arising from one long common stem; stem broad, covered with many spicules, and with a strengthening rib along inner side; 2 pairs of filaments near base of stem and one pair on end of stem always petiolate while 6 filaments arising from the part between these pairs usually sessile. Head and thorax with normal tubercles, trichomes fine and hairlike. Abdomen with normal complement of hooks consisting of 4 on each side dorsally on segments III-IV, and 2 on each side ventrally on segments V-VII, ventral ones on segment $\mathrm{V}$ closer together than those on succeeding segments; spine comb present dorsally on segments VI-VIII; caudal spines very short. Cocoon simple, slipper-shaped without neck and anterior median projection, rather closely woven.

Larva : Length $3.75-4.70 \mathrm{~mm}$. General body color pale brownish-yellow.

Head capsule creamy-yellow; head spots on cephalic apotome of negative pattern; antero-median and postero-median head spots clearly delimited as usual but anterolateral and postero-lateral head spots not delimited; side of head with clear area surrounding eye spots and with a distinct brown speckle behind eye spots; eyebrow as usual inconspicuous. Postgenal cleft deep and broad, mitre-shaped; its depth almost equal to the maximum breadth in size. Hypostomium as in Fig. 1, median and corner teeth of apical teeth moderately prominent and intermediate teeth subequal in size. Antenna slender and longer than stalk of cephalic fan, only 

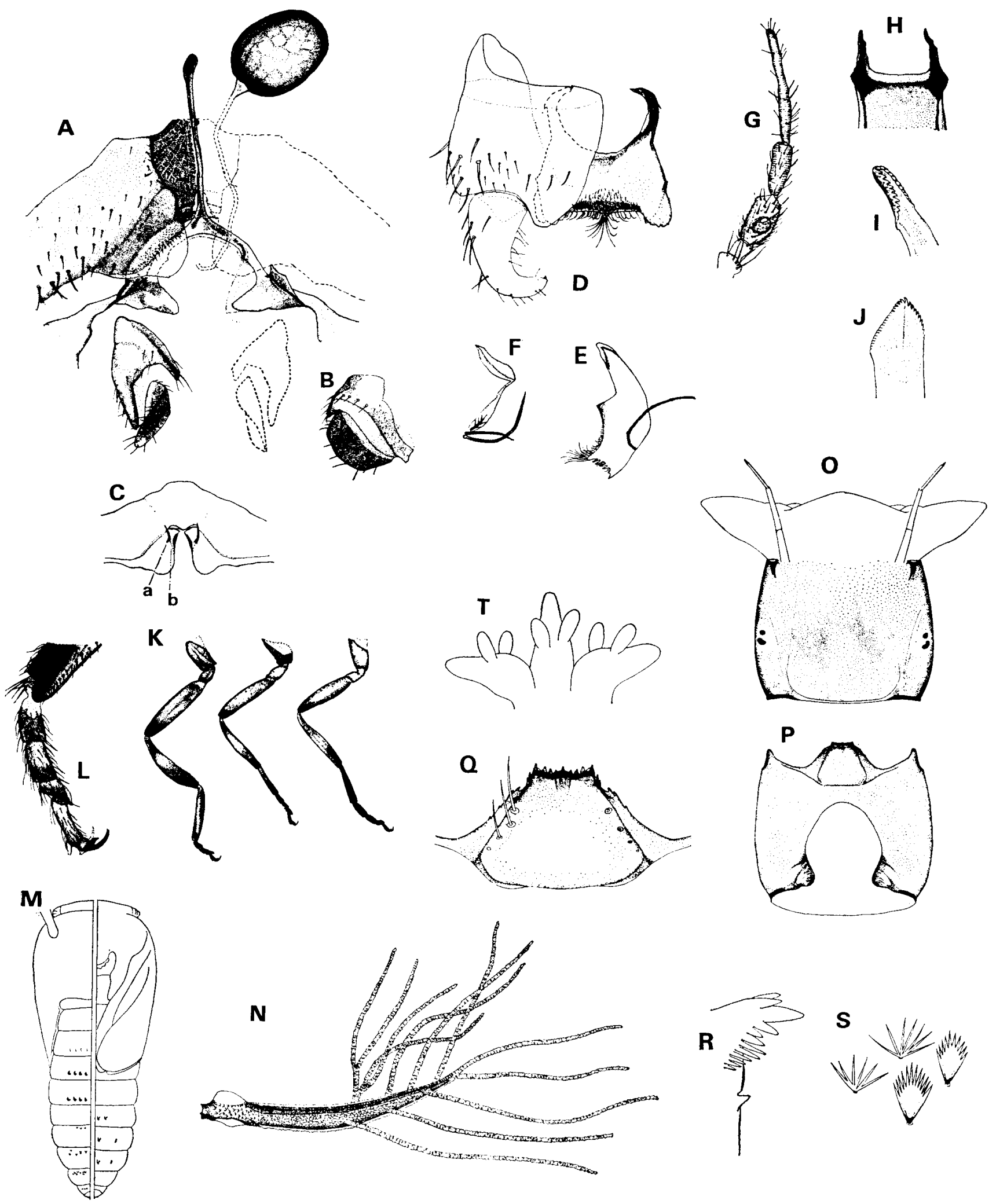

Fig. 1 Simulium (Pomeroyellum) arcashense n. sp.

$\mathrm{A}-\mathrm{C}$ and $\mathrm{G}-\mathrm{L}$; female, D-F ; male, $\mathrm{M}-\mathrm{H}$; pupa, O-T ; larva

A ; genitalia, B ; ditto, cercus, C ; ditto, ovipositor lobe pressed dorso-ventrally (a ; chitinous process, b; fold), D; genitalia, E; ditto, ventral plate in lateral view, F; ditto, paramere, $\mathrm{G}$; maxillary palp, $\mathrm{H}$; cibarium, I ; maxilla, J ; mandible, $\mathrm{K}$; legs, $\mathrm{L}$; hind tarsi, $\mathrm{M}$; arrangement of hooks dorsally and ventrally, $\mathrm{N}$; respirator organ, $\mathrm{O}$; head capsule in dorsal view, $\mathrm{P}$; ditto, in ventral view, $\mathrm{Q}$; hypostomium, $\mathrm{R}$; mandible, $\mathrm{S}$; dorsal scales on abdominal segments, $\mathrm{T}$; rectal gill 
lightly pigmented basally on first segment; proportional length of segments I-IV about $11: 14: 9: 1$; second annulations not present. Mandible of typical form, with a moderately long tooth and one or two minute teeth on inner subapical margin; the second of subapical teeth much smaller than the first and slightly shorter than the third. Maxillary palp about 3.3 times as long as breadth at base. Cephalic fan $30-38$ rays. Thorax pale yellowish-grey. Lateral plate of proleg relatively slender, lightly pigmented, extending to two-thirds length of apical segment. Each abdominal segment pale yellowish-grey, with brown segmental mottling. Cuticle of posterior segments dorsally with numerous, erect, dark brown scales and short, erect, slightly pigmented tufts as in Fig. 1, but last segment without accessory sclerites. Ventral papillae distinct. Rectal gill trifid; each lobe with thumb-like secondary lobules. Anal sclerite of usual type; posterior arms rather strongly pigmented than anterior arms, extending to about 12 th row of hooks. Posterior circulet consisting of 6-12 hooks in 60-68 rows.

Holotype. Female (reared) preserved in alcohol solution, Type NSMT-I-Dipt. No. 03821, National Science Museum, Tokyo, Japan.

Type locality. Awash River near the Sodore Spring, Shoa Province, Ethiopia; pupa collected on May 14, 1973 by K. Uemoto and Yemane $\mathrm{M}$.

Allotype. Male (reared) preserved in alcohol solution, Type NSMT-I-Dipt. No. 03822, National Science Museum, Tokyo, same data.

Paratype I. 1 female and 1 male (all reared) preserved in alcohol solution, Type NSMT-I-Dipt. No. 03823-03824, collected from same place as that of holotype on June 21, 1973 by K. Uemoto and Yemane M. ; 5 larvae preserved in alcohol solution, Type NSMT-I-Dipt. No. 03825, collected from same place as above specimens, on Jan. 24, 1973 by K. Uemoto and Yemane M. ; 20 larvae preserved in alcohol solution, Type NSMT-I-Dipt. No. 03826, collected from Gibe River crossing the road from Addis Ababa To Jimma, Kaffa Province, Ethiopia, on July 27, 1973 by K. Uemoto and
Yemane M. (All of the specimens are kept in the National Science Museum, Tokyo.)

Paratype II. 1 male (reared) preserved in alcohol solution, collected from same place as that of holotype, at May 14, 1973 by K. Uemoto and Yemane M.; 20 larvae preserved in alcohol solution, collected from Gibe River crossing the road from Addis Ababa to Jimma, Kaffa Province, Ethiopia, at July 27, 1973 by K. Uemoto and Yemane M. (All of the specimens are kept in the Central Laboratory and Research Institute, Ethiopia.)

Records (Map 1).

Materials examined. Adults reared from pupae-Awash River near Sodore Spring, Shoa Province, 14-V-1969, K. Ogata and Masakazu Takahashi; Gibe River crossing the road from Addis Ababa to Jimma, Kaffa Province, 7-VIII-1969, K. Ogata and M. Takahashi; Gunntate River crossing the road between Awash and Mieso, Harrar Province, 15-VIII-1969, K. Ogata and M. Takahashi; Erer River Trib. near Erer Plantation along the road between Dire Dawa and Mieso, Harrar Province, 18-VIII-1969, K. Ogata and M. Takahashi; Abbai River Trib. crossing the road between Bahar Dar and Danghela, Gojjam Province, 17-XII-1969, K. Ogata and M. Takahashi; adults reared from pupae and larvae-Gojeb River crossing the road from Bonga to Jimma, Kaffa Province, 2-XI-1972, K. Uemoto and Yemane M. ; Genale River crossing the road from Negele, Sidamo Province, 29-XII-1972, K. Uemoto and Yemane M. ; Billate R. crossing the road between Shashemane and Soddo, Shoa Province, 8-II-1973, K. Uemoto and Yemane M. ; Laga Meki R. crossing the road from Ambo to Nekempt, Wollega Province, 14-VII-1973, K. Uemoto and Yemane M. ; Diddesa $R$. crossing the road between Nekempt and Gimbi, Wollega Province, 17-VII-1973, K. Uemoto and Yemane M. ; Gibe River crossing the road from Addis Ababa to Jimma, Kaffa Province, 27-VII1973, K. Uemoto and Yemane M.; Little Gibe River Trib. running out from Hippo. Swamp near Jimma, Kaffa Province, 9-VIII1973, K. Uemoto and Yemane M.

Remarks. Pupae and adults of this species closely resemble to those of Simulium momahoni de Meillon as mentioned above. 


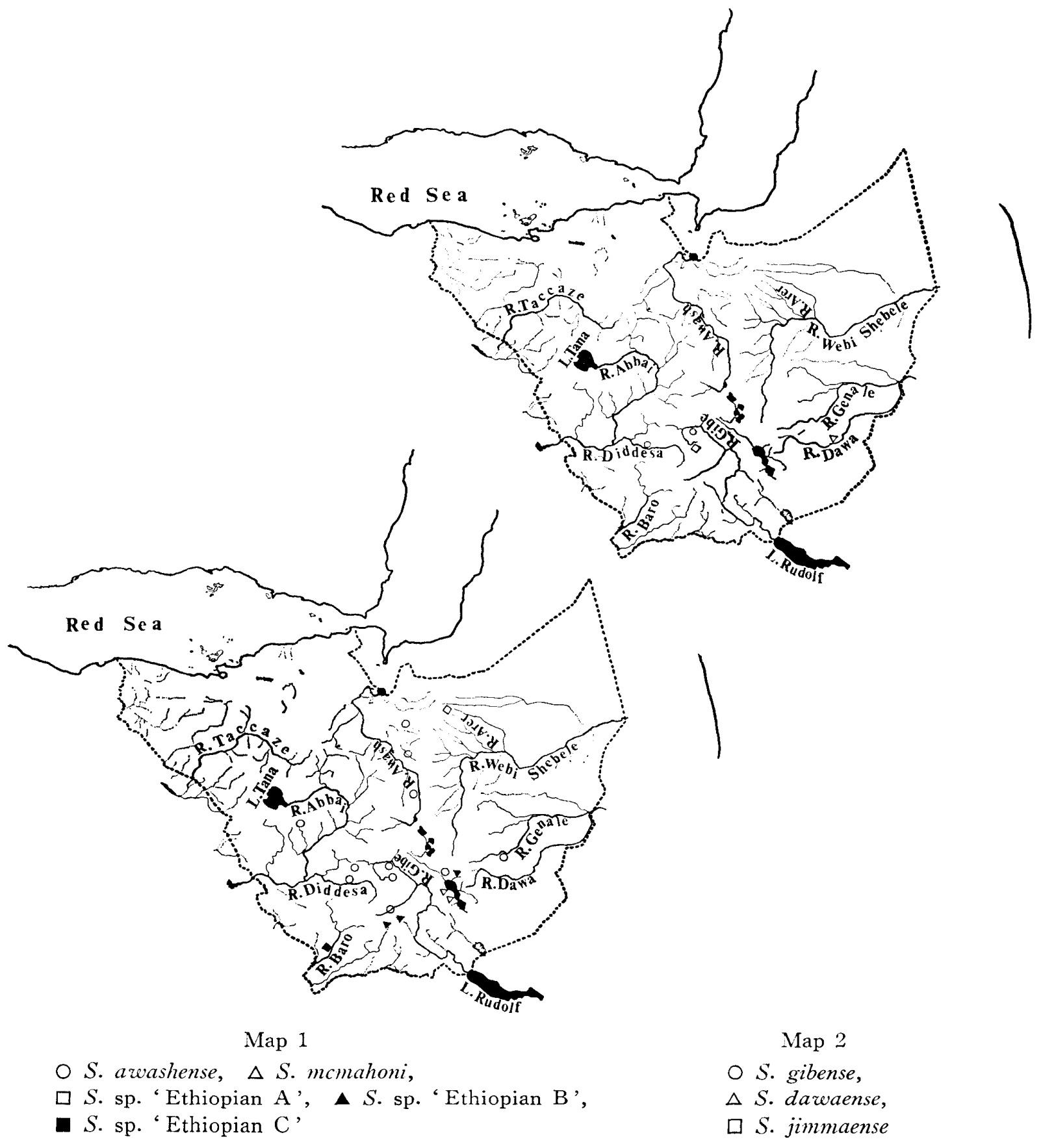

But, in this pupa, respiratory organs of all specimens examined have had 12 filaments on a common stem, except for a few specimens with 10 filaments collected by $\mathrm{K}$. Ogata and M. Takahashi from Gunntate and Erer River, Harrar Province, Ethiopia. Ventral plate of male genitalia of this species has postero-medial projection strongly upturned, and more developing posterior shoulders than those of $S$. momahoni. Further, this larva is clearly differentiated from that of $S$. mcmahoni by having the longer second segment of antenna than the first, also than the third, and by having broader postgenal cleft, of which maximum breadth equals to its depth in size, whereas the depth of the postgenal cleft of $S$. momahoni is much longer than its maximum breadth.

Biological notes. The pupae and larvae of this species are found at the reaches where the current is rather slow in rivers with large width, often in company with $S$. damnosum, throughout the year.

In Ethiopia this species is very commonly distributed, but the locality does not overlap that of $S$. mcmahoni, as shown in Map 1 . 


\section{Simulium (Pomeroyellum) sp. 'Ethiopian A'}

Female, male and larva. Not known.

Pupa. Length about $3.80 \mathrm{~mm}$. Respiratory organ about $2.60 \mathrm{~mm}$, with six filaments as in Fig. 5. Head and thorax with normal tubercles and fine trichomes. Abdominal onchotaxy normal, one minute hook each side ventrally on segment IV in addition; caudal spines very small, slightly curved. Cocoon simple, slipper-shaped, without neck.

Systematic position. This pupa seems to resemble closely to that of $S$. loutetense, placed into the subgenus Eusimulium by Crosskey (1969), or to that of S. sexiens of the subgenus Meilloniellum because in having normal abdominal onchotaxy and respiratory organ with six filaments. However, in $S$. loutetense or $S$. sexiens, all pairs of filaments are sessile or very shortly petiolate, especially the dorsal pairs are without so long petiole as that of this species. This species could better be placed in the alcocki-group of the subgenus Pomeroyellum than in the subgenus Meilloniellum or Eusimulium, because of the branching mode of its respiratory organ.

Material examined. Arer River crossing the road from Harrar to Jijiga, Harrar Province, 17-VIII-1969, 4 pupae collected by K. Ogata and M. Takahashi.

\section{Simulium (Pomeroyellum) sp. 'Ethiopian B'}

Female. Terminaria got by dissecting of pupae as in Fig. 5. Ovipositor lobe rounded at apex, with a distinctly chitinous process near its inner base; inner margin narrowly pigmented. Genital fork spatulate at extreme base; its arms short, narrow, slightly curved; distal end of arm with anterior and postero-medial processes, anterior one large, blunt, postero-medial one rather indistinct. Cercus relatively large and subtriangulate in profile. Anal lobe relatively narrow, with projecting antero-inner corner.

Male. Not known.

Pupa. Length about $3.50 \mathrm{~mm}$. Respiratory organ about $2.80 \mathrm{~mm}$, with ten filaments as in Fig. 5. Head and thorax with normal tubercles and fine trichomes. Abdominal onchotaxy normal ; two small supernumerary hooks each side ventrally on segment IV; caudal spines minute, blunt at apex. Cocoon simple, slipper-shaped, without neck.

Larva. Length $3.90-4.35 \mathrm{~mm}$. General body color pale brownish-yellow. Head capsule pale brownish-yellow with indistinct negative pattern of head spots on cephalic apotome; side of head pale brownish-yellow except for clear area surrounding eye spots; eyebrow inconspicuous. Postgenal cleft relatively narrow, distinctly rounded apically; lateral margins slightly curved. Postgenal bridge a little shorter than length of hypostomium. Hypostomium with median and corner teeth moderately prominent from intermediate teeth. Antenna slender, longer than stalk of cephalic fan, slightly pigmented basally on first segment; proportional length of segments I-IV about $13: 10: 13: 1$. Mandible of typical form, with inner serrations consisting of a moderately long tooth and a following fine tooth; second comb tooth smaller than first or third. Maxillary palp about 3.0 times as long as breadth at base. Cephalic fan with 24-30 rays. Thorax pale yellowish-grey; cuticle of segment dorsally with numerous short, erect tufts in addition to impukane-like scales as in Fig. 5. Ventral papillae distinct. Rectal gill trifid; each lobe with one or two thumb-like secondary lobules. Anal sclerite usual type; posterior arms extending to about 14th row of hooks. Posterior circulet consisting of 514 hooks in 76-80 rows.

Systematic position. This species appears to be assigned to the alcocki-group of the subgenus Pomeroyellum and bears striking resemblances to the species of this group, $S$. weyeri Garms and Häuserman, 1968. However, the pupa of this species is distinct from that of $S$. weyeri on the branching mode of respiratory organ and this larva is differentiated from that of $S$. weyeri in having some impukane-like scales in addition to short, erect tufts as in $S$. weyeri on its dorsal abdominal cuticle.

Material examined. Shuro River Trib. crossing the road from Bonga to Ghimira near the entrance of Dakia Forest, Kaffa Province, 8-VII-1969, one pupa collected by K. Ogata and M. Takahashi ; Chiccia River 

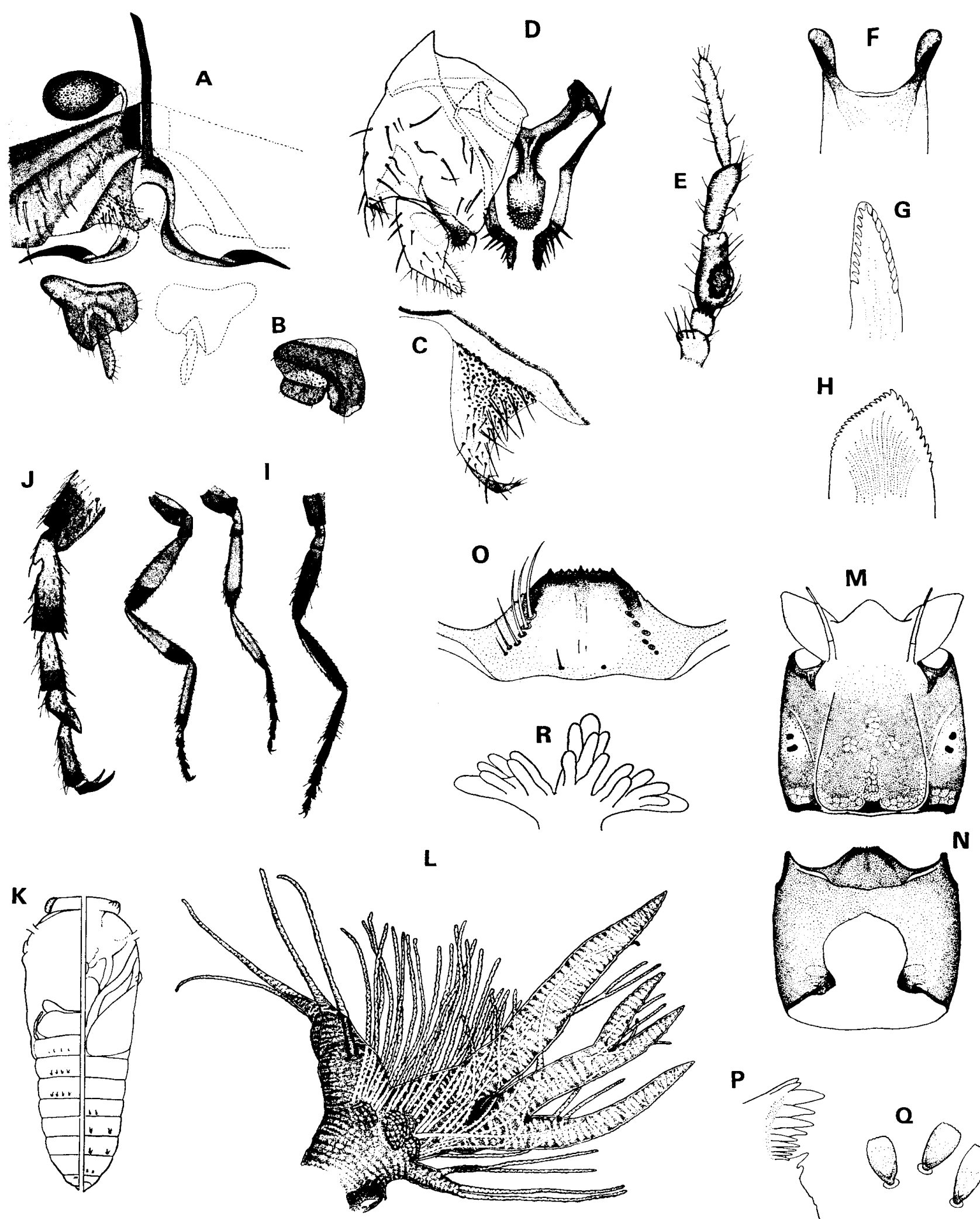

Fig. 2 Simulium (Metomphalus) gibense $\mathrm{n} . \mathrm{sp}$.
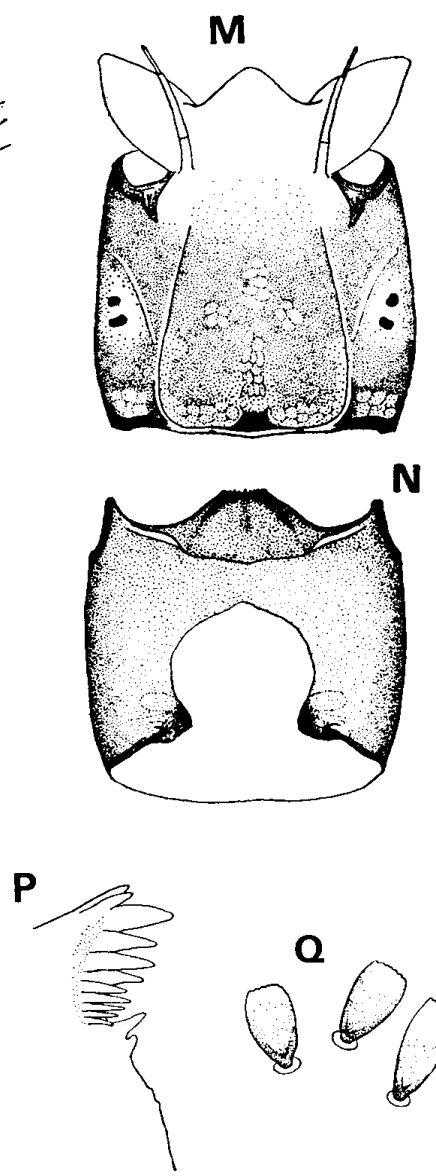

$\mathrm{A}-\mathrm{C}$ and $\mathrm{E}-\mathrm{J}$; female, D ; male, $\mathrm{K}-\mathrm{L}$; pupa, M-R ; larva

A ; genitalia, $\mathrm{B}$; ditto, cercus, $\mathrm{C}$; ditto, bristles on the surface of ovipositor lobe, $\mathrm{D}$; genitalia, E; maxillary palp, $\mathrm{F}$; cibarium, $\mathrm{G}$; maxilla, $\mathrm{H}$; mandible, I ; legs, $\mathrm{J}$; hind tarsi, K; arrangement of hooks dorsally and ventrally, L; respiratory organ, $M$; head capsule in dorsal view, $\mathrm{N}$; ditto, in ventral view, $\mathrm{O}$; hypostomium, $\mathrm{P}$; mandible, $\mathrm{Q}$; dorsal scales on abdominal segments, $\mathrm{R}$; rectal gill 

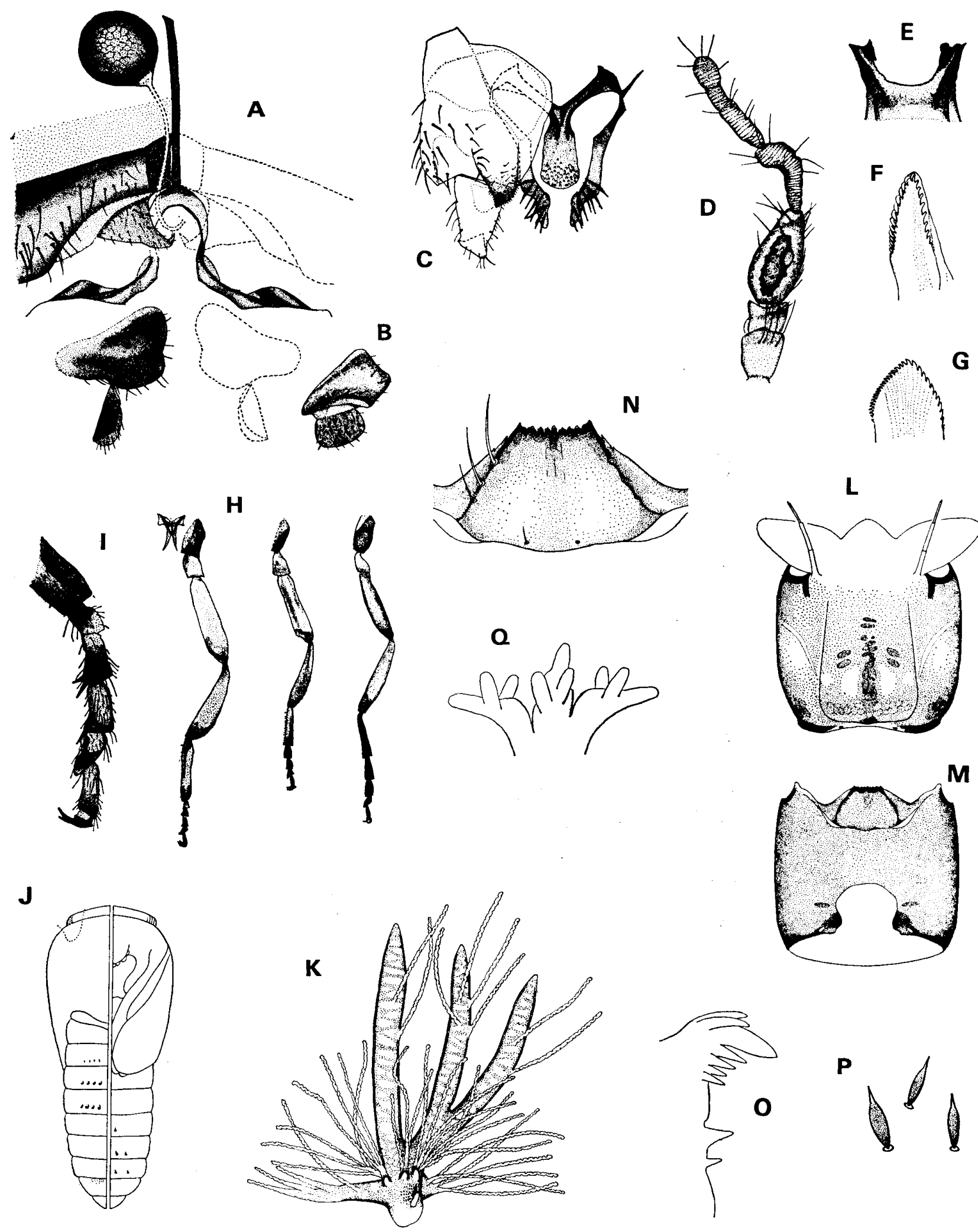

$\mathbf{L}$
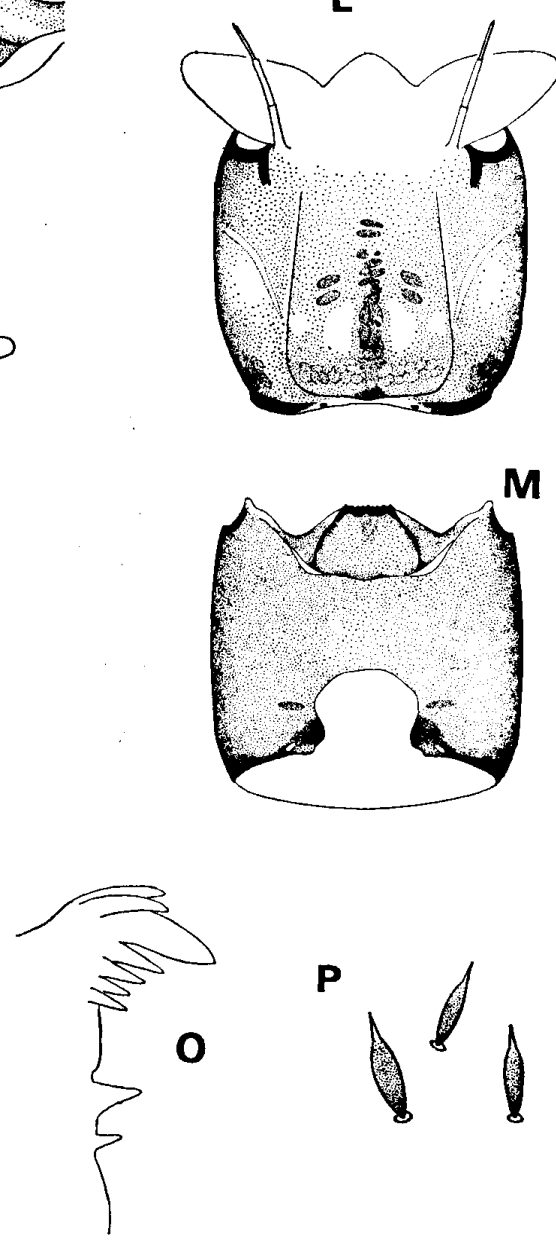

Fig. 3 Simulium (Metomphalus) dawaense n. sp.

A-B and D-I ; female, C; male, J-K; pupa, L-Q ; larva

A ; genitalia, B ; ditto, cercus, C ; genitalia, D ; maxillary palp, E; cibarium, F ; maxilla, $\mathrm{G}$; mandible, $\mathrm{H}$; legs, $\mathrm{I}$; hind tarsi, $\mathrm{J}$; arrangement of hooks dorsally and ventrally, $\mathrm{K}$; respiratory organ, $\mathrm{L}$; head capsule in dorsal view, $\mathrm{M}$; ditto, in ventral view, $\mathrm{N}$; hypostomium, $\mathrm{O}$; mandible, $\mathrm{P}$; dorsal scales on abdominal segments, $\mathrm{Q}$; rectal gill 

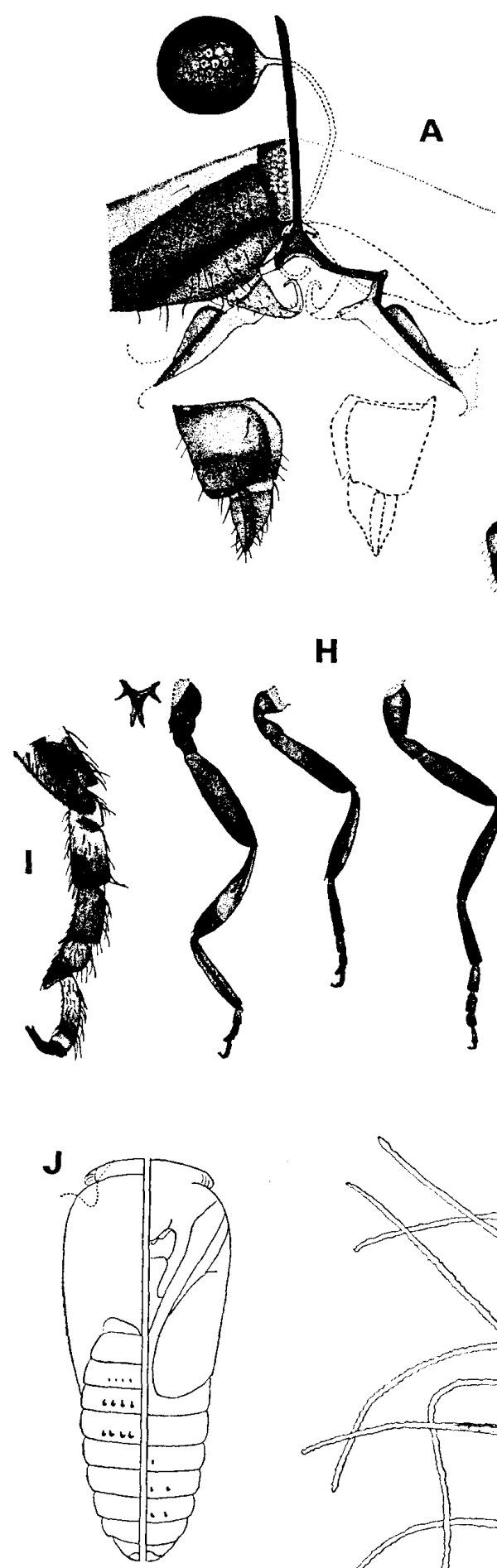

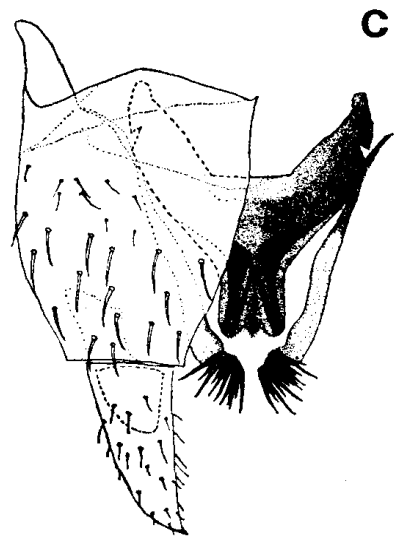

C
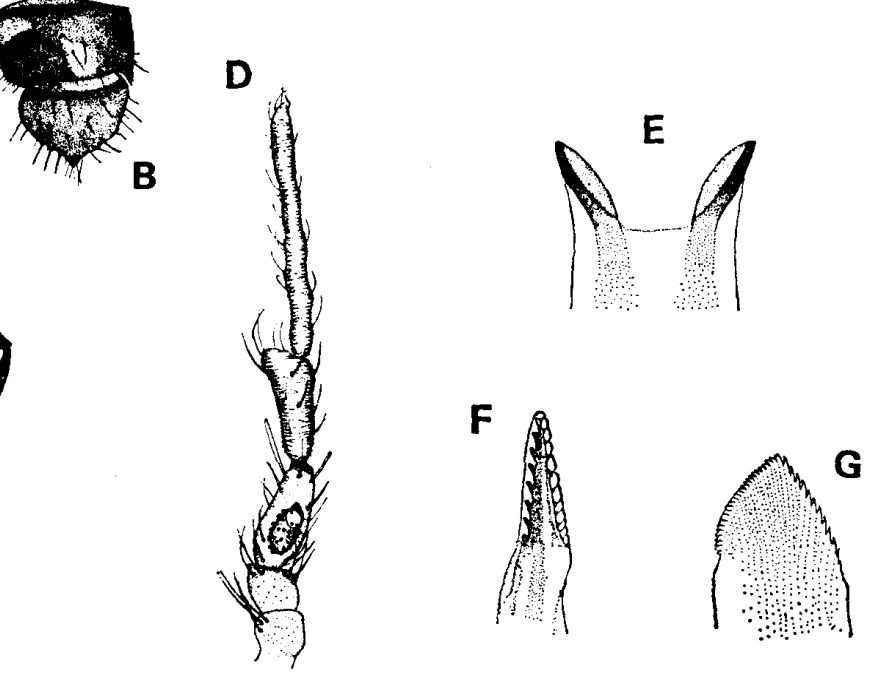

Fig. 4 Simulium (Metomphalus) jimmaense n. sp.

$\mathrm{A}-\mathrm{B}$ and $\mathrm{D}-\mathrm{I}$; female, $\mathrm{C}$; male, J-K; pupa

$\mathrm{A}$; genitalia, B ; ditto, cercus, $\mathrm{C}$; genitalia, D ; maxillary palp, E ; cibarium, F ; maxilla, $\mathrm{G}$; mandible, $\mathrm{H}$; legs, I; hind tarsi, $\mathrm{J}$; arrangement of hooks dorsally and ventrally, $\mathrm{K}$; respiratory organ 


\section{A}
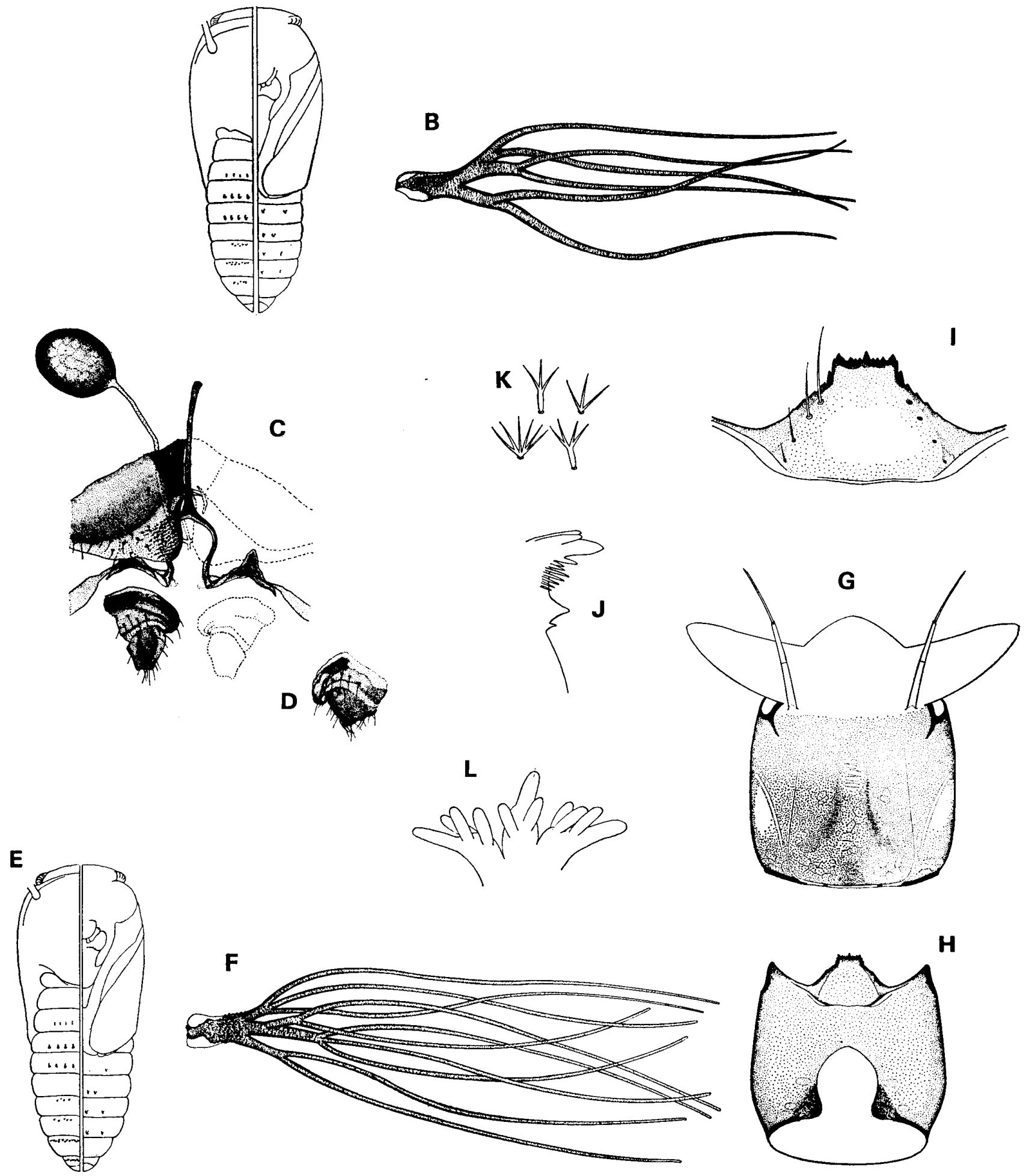

Fig. 5 A-B; Simulium (Pomeroyellum) sp. 'Ethiopian A', pupa A ; arrangement of hooks dorsally and ventrally, B ; respiratory organ

C-L ; Simulium (Pomeroyellum) sp. 'Ethiopian B' C; female genitalia, D ; ditto, cercus, E-F ; pupa, G-L; larva, E ; arrangement of hooks dorsally and ventrally, F; respiratory organ, $\mathrm{G}$; head capsule in dorsal view, $\mathrm{H}$; ditto, in ventral view, I; hypostomium, J ; mandible, $\mathrm{K}$; dorsal scales on abdominal segments, $\mathrm{L}$; rectal gill 
Trib. crossing the road from Jimma to Bonga near the entrance of Bonga Town, Kaffa Province, 3-XI-1972, 2 larvae collected by K. Uemoto and Yemane M. ; Shuro River Trib. crossing road from Bonga to Ghimira near Washwush Village, Kaffa Province, 6XI-1972, 1 larva and 1 pupa collected by K. Uemoto and Yemane M. ; Loki Stream crossing the road from Shashemane to Dilla near the entrance of Dilla Town, Sidamo Province, 30-XII-1972, 10 larvae collected by $\mathrm{K}$. Uemoto and Yemane $\mathrm{M}$.

\section{Simulium (Pomeroyellum) sp. 'Ethiopian C'}

Female. Terminalia got from pupa as in Fig. 6. Ovipositor lobe blunt at apex, with distinctly chitinous process near its inner base; inner margin narrowly pigmented.
Genital fork spatulate at extreme base; arms short, rather narrow, slightly curved; distal end of arm with a small, heavy pigmented anterior process and a well developed postero-medial process. Cercus relatively large and subtriangulate in profile. Anal lobe rather broad, with projecting antero-inner corner.

Male. Not known.

Pupa. Length about $3.20 \mathrm{~mm}$. Respiratory organ about $2.40 \mathrm{~mm}$, consisting of ten filaments arranged $3,2,2,3$, as in Fig. 6, 4 forks occur in basal half of the organ. Head and thorax with normal tubercles and fine trichomes. Abdominal onchotaxy normal; caudal spines small, slightly curved. Cocoon slipper-shaped, simple.

Larva. Length $3.30-3.65 \mathrm{~mm}$. General body color pale yellowish-grey. Head capsule
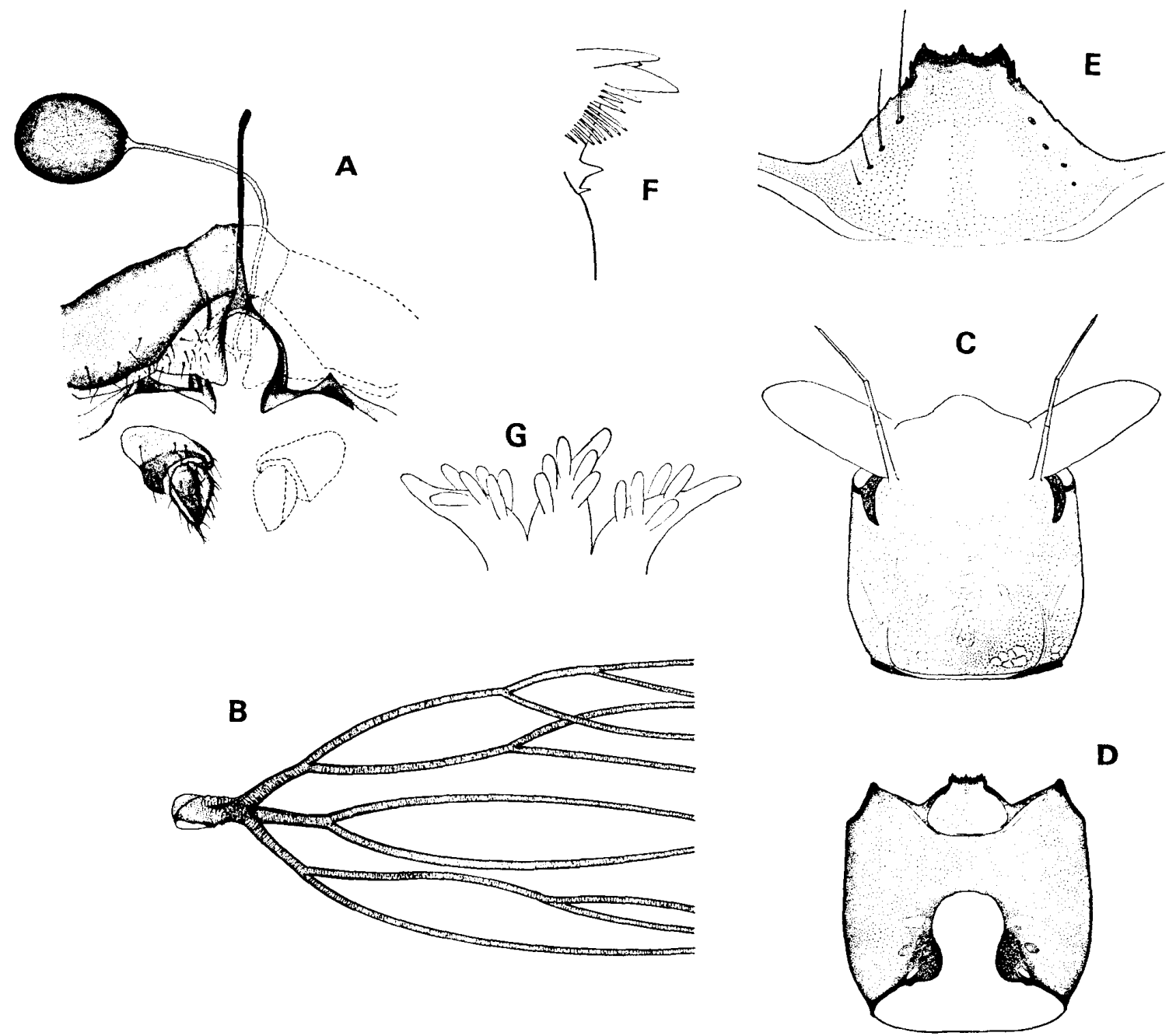

Fig. 6 Simulium (Pomeroyellum) sp. 'Ethiopian C'

A ; female genitalia, B; pupal respiratory organ, $C-G$; larva, $C$; head capsule in dorsal view, $\mathrm{D}$; ditto, in ventral view, $\mathrm{E}$; hypostomium, $\mathrm{F}$; mandible, $\mathrm{G}$; rectal gill 
pale brownish-yellow; head spots on cephalic apotome of distinct negative pattern; side of head pale brownish-yellow except for clear area surrounding eye spots; eyebrow conspicuous. Postgenal cleft relatively deep and wide, anterior margin rounded but with a slight trace of a widely obtuse angle, lateral margin curved. Postgenal bridge slightly shorter than hypostomium. Hypostomium with median and corner teeth prominent from intermediate teeth. Antenna slender, longer than stalk of cephalic fan, not pigmented; proportional length of segments I-IV about $9: 8: 12: 1$. Mandible of typical form with inner serrations consisting of two teeth, moderately long one and small one; second comb tooth much smaller than first and shorter than third. Maxillary palp about 2.8 times as long as breadth at base. Cephalic fan with 28-32 rays. Thorax pale yellowish-grey. Lateral plate on apical segment of proleg very lightly pigmented, narrow. Each abdominal segments pale yellowish-grey with brown segmental mottling dorsally, especially mottling on first segment dark ; dorsal cuticle of segments without any pigmented, broad or branched scales, but only with scattered, minute hairs. Rectal gill trifid ; each lobe with 2-5 thumb-like lobules. Ventral papillae distinct. Anal sclerite usual type; posterior arms extending to about the 11th row of hooks. Posterior circulet consisting of 4-12 hooks in 57-64 rows.

Systematic position. This species appears to be assigned to the alcocki-group of the subgenus Pomeroyellum and closely related to $S$. djallonense or $S$. garmsi, but is different from them in the shape of larval postgenal cleft as well as the dorsal abdominal cuticle of the larva without branched scales.

Material examined. Gole River Trib. crossing the trail, about $12 \mathrm{~km}$ north-west of Gambela Airport, Illubabor Province, 3-V1973, 114 larvae and 2 pupae collected by K. Uemoto and Yemane $\mathrm{M}$.

\section{Simulium (Metomphalus) gibense new species}

Female. General body color brownishblack to black. Length: body 2.15-2.43 $\mathrm{mm}$, wing $2.20-2.65 \mathrm{~mm}$.

Head blackish-brown with faint pale yel- low pollinosity; frons with long pale yellow hairs. Clypeus faintly grey pollinose, sparsely with long pale yellow hairs. Occiput rather dense with moderately long, pale yellow pile. Antenna 11-segmented; scape, pedicel and basal half of first flagellomere yellow; remaining segments brownish-black. Mandible with 28-32 serrations. Blade of maxilla with about 10 inner and $7-8$ outer retrorse teeth. Maxillary palpus pale brown to blackish-brown, with black hairs; segment $\mathrm{V} 1.5$ times as long as segment III; basal one-third of segment III abruptly thick. Sensory vesicle large, ellipsoid-shaped, about half as long as its segment, proximally situated; neck short, arising from anterodorsal surface of vesicle, directed vertically. Thorax blackish-brown to black; scutum lightly greyish pollinose, showing definite pattern consisting of 3 rather wide, dark stripes medially with light coming from in front, covered with short, recumbent, pale yellow pile that is longer laterally and postero-medially; scutellum brown with pale yellow and greyish hairs. Pleural membrane haired; katepisternum and postnotum bare. All femora yellowish-brown with darker terminal end. Fore tibia lightly brown, darkened at basal 1/4 and apical 1/3. Mid and hind tibiae pale yellowish-brown with narrow, white patch laterally and distal $1 / 5$ black. Fore tarsi not enlarged, darkened. Mid and hind tarsi black except with basimere. Hind metatarsus narrow, parallelsided, about 7 times as long as broad, pale yellow, with black patch on distal $1 / 4$ and along frontal side. Calcipara and pedisulcus well developed. All claws simple. Wing hyaline; basal section of radius haired; basal hair tufts brownish-yellow. Knob of haltere pale yellowish. Abdomen blackishbrown, evenly clothed with golden hairs that are longer laterally; baral fringe yellow. Terminalia as in Fig. 2; ovipositor lobe forms pointed subtriangular process that is slightly curled apically, with numerous stout hairs strongly widened basally. Genital fork spatulate at base; arms strongly arched, of which distal half curved subrectangularly against basal half, without any projection; distal end heavily sclerotized, widely attached with segment IX. Spermatheca ovate, 
with faint surface reticulation. Cercus moderately large, about twice as broad as long, subquadrate in profile, with rounded posterior corners. Anal lobe broader ventrally, heavily sclerotized, with simple flap rounded apically.

Male. General body color brownish-black. Length : body $2.45-2.65 \mathrm{~mm}$, wing 2.00-2.05 $\mathrm{mm}$.

Frons and clypeus brownish-black with a few pale grey hairs. Upper eye facet in about 18 rows. Occiput with long pile mixed with pale yellow and lightly grey hairs. Antenna as in female except for only two basal segments yellow. Scutum brownish-black, with lightly grey pollinosity, and shows the pattern with a broad, dark, longitudinal stripe medially, covered with short, recumbent, pale yellow pile that becomes more sparse medially. Fore metatarsus not enlarged, about 7.5 times as long as maximum breadth. Genitalia as shown in Fig. 2. Style tapering, curved at apical third of its length, about two-thirds as long as coxite, with a minute spine at apex. Coxite broad, 1.3 times as long as maximum breadth; its hind inner corner produced beyond base of style, strongly sclerotized at apex. Body of ventral plate narrow, rounded distally, densely covered with numerous minute bristles on its apical half. Median sclerite broadly expanded apically. Paramere with numerous hooks.

Pupa. Length: boby $2.80-3.00 \mathrm{~mm}$, respiratory organ $0.65-0.70 \mathrm{~mm}$. Head and thorax with normal tubercles and fine trichomes. Respiratory organ complex, with five, thick, blunt, primary filaments and a number of thin secondary filaments arising from these primaries; ventral one (the first) of primaries thickest but short, extending forward; the second one longest; the third one forked distally; last one shortest and narrowest as in Fig. 2. Abdomen with normal complement of hooks, consisting of four hooks each side dorsally on segments III-IV and a pair of hooks each side ventrally on segments V-VII, but the latter hooks on segment $\mathrm{V}$ extremely minute or degenerate. Dorsal spine comb on segments VI-IX absent. Cocoon shoe-shaped, with well formed neck.

Larva. Length $4.85-5.45 \mathrm{~mm}$. General body color pale greyish-brown. Head capsule yellowish-brown; cephalic apotome pale yellowish-brown, only with extreme, darker patch postero-medially; head spots indistinct but not of negative pattern, anterolateral and median spots of them faintly distinguishable from surrounding pigmentation, postero-lateral spots less distinct than others; side of head evenly yellowish-brown excepting its hind margin strongly sclerotized, with clear area surrounding eye spots ; eyebrow as usual inconspicuous. Postgenal cleft deep and broad, mitre-shaped, its depth slightly shorter than the maximum breadth. Hypostomium as in Fig. 2, with 9 apical teeth ranging in substraight; median tooth of them slightly prominent, corner and intermediate teeth blunt and subequal in size. Hypostomial setae 6-8 in each row, diversing posteriorly from lateral margin of hypostomiun. Antenna slender and longer than stalk of cephalic fan, slightly pigmented on segments I, III and distal half of II ; proportional length of segments I-IV about $6: 11: 7: 1$; second annulation not present. Mandible of typical form, with one moderately long tooth and followed by minute one subapically on inner margin; all comb teeth long, subequal in length. Maxillary palp about 3.3 times as long as breadth at base. Cephalic fan 40-50 rays. Thorax pale greyish-brown. Lateral plate of proleg obscure. Each abdominal segment yellowishbrown, rather darker dorsally. Cuticle of posterior segments dorsally with numerous flattened spatulate scales as in Fig. 2. Ventral papillae absent. Rectal gill trifid; each lobe with numerous secondary lobules. Rectal scales sparsely present. Anal sclerite of usual type; posterior arms longer than anterior arms, extending to about 28th row of hooks. Posterior circulet consisting of 830 hooks in $150-158$ rows.

Holotype. Female (reared) preserved in alcohol solution, Type NSMT-I-Dipt. No. 03827, National Science Museum, Tokyo, Japan.

Type locality. Gibe River crossing the road from Addis Ababa to Jimma, Kaffa Province, Ethiopia, pupa collected on Jan. 12, 1974 by Yemane M.

Allotype. Male (reared) preserved in alco- 
hol solution, Type NSMT-I-Dipt. No. 03828, National Science Museum, Tokyo, same data. Paratype I. Male (reared) preserved in alcohol solution, Type NSMT-I-Dipt. No. 03829, same data; 1 female and 1 male (all reared) mounted on slides, Type NSMT-IDipt. No. 03830-03831, collected from Gibe River crossing the road from Addis Ababa to Jimma, Kaffa Province, on Aug. 7, 1969, by K. Ogata and M. Takahashi; 5 pupae preserved in alcohol solution, Type NSMT-IDipt. No. 03832, same data as series of holoand allotype; 5 larvae preserved in alcohol solution, Type NSMT-I-Dipt. No. 03833, same data as series of holo- and allotype except on July 27, 1973 by K. Uemoto and Yemane M. (All of the specimens are kept in the National Science Museum, Tokyo, Japan.)

Paratype II. 1 female (reared) preserved in alcohol solution, same data as series of mounted slides ; 1 male (reared) and 5 larvae preserved in alcohol solution, same data as larval series of Paratype I. (All of the specimens are kept in the Central Laboratory and Research Institute, Addis Ababa, Ethiopia.)

Records (Map 2).

Materials examined. Females by biting collection—bank of Gibe River crossing the road from Addis Ababa to Jimma, Kaffa Province, 10-VII-1969, K. Ogata and M. Takahashi; same station, 7-VIII-1969, by same collectors. Adults reared from pupae - Gibe River crossing the road from Addis Ababa to Jimma, 7-VIII-1969, K. Ogata and M. Takahashi; same station, 27-VII1973, K. Uemoto and Yemane M. ; same station, 12-I-1974, Yemane M. Larvaesame station, 27-VII-1973, K. Uemoto and Yemane M.; Didessa River crossing the road between Nekempt and Gimbi, Wollega Province, 17-VII-1973, K. Uemoto and Yemane M.

Remarks. This species appears to resemble to Simulium (Metomphalus) fragai Marini de Araújo Abreu (1960) from Angola, especially, on the shapes of pupal respiratory organ. But, basal arms of respiratory organ of the latter are less developed than those of the former. Apparently, these adults are similar to those of $S$. fragai except for the pleural membrane is haired ( $S$. fragai: "membrana pleural glabra"), and differ in the details of the genitalia. The ventral plate is much narrower than in S. fragai and the ovipositor lobes are broader, with numerous stout hairs strongly widened basally, whereas these are not so in $S$. fragai. This species seems to fall between the bovisand medusaeforme-group of the subgenus Metomphalus in its taxonomic features, which are defined by Crosskey (1969), because the dorsal scales on the abdominal segments of the larva are blunt, flattened as in the bovisgroup, on the other hand, a pair of hooklets are present ventrally on each side of the abdominal segment $\mathrm{V}$ of the pupa like the medusaeforme-group. However, we would prefer to place it into the bovis-group on account of the fact tact that this character of the pupa is highly degenerate.

Biological notes. During the rainy season of 1969, K. Ogata, one of the authors, caught a total of 35 females of this species in two biting collections on the bank of the Gibe River crossing the road between Addis Ababa and Jimma and confirmed some of them to suck blood from human beings. This fact shows $S$. (M.) gibense to be the third man-biting species, as Simulium damnosum and $S$. woodi ethiopiense are known to be anthro-pophilic in Ethiopia. The larvae are developed in fast-flowing broad rivers together with $S$. damnosum all the year round, but man-biting behaviour appears to be manifested only during the rainy season.

The possible role of this species in the transmission of onchocerciasis should be investigated because the localities of this species are foci of this disease infection.

\section{Simulium (Metomphalus) dawaense new species}

Female. General body color brownishblack to black. Length : body $2.45-2.75 \mathrm{~mm}$, wing $2.30-2.55 \mathrm{~mm}$.

Head blackish-brown with faint white pollinosity; frons with sparsely and moderately long, white hairs. Clypeus faintly pale yellow pollonose, rather dense and with moderately long, pale yellow hairs. Occiput with densely long, white pile. Antenna 11 
segmented; scape, pedicel and basal about one-third of first flagellomere yellow, remaining segments brownish-black. Mandible with 34-37 serrations. Blade of maxilla with about 13 inner and 8 outer retrorse teeth. Maxillar palpus yellowish-brown to blackishbrown with black hairs; segment V 1.5 times as long as segment III ; segment III subellipsoid in shape becoming narrower apically. Sensory vesicle long, ellipsoid in shape, about two-thirds as long as its segment, proximally situated; neck rather long, arising from antero-dorsal surface of vesicle, directed vertically. Thorax blackish-brown to black; scutum faintly greyish pollinose, showing rather indistinct pattern consisting of 3 narrow dark stripes medially, rather densely covered with moderately long, recumbent, pale yellow pile that is longer laterally; scutellum brown with long, pale yellow and greyish hairs. Pleural membrane sparsely with long, yellow hairs; katepisternum and pronotum bare. All femora yellowish-brown with darker terminal end. Fore tibia lightly brown, darkened at apical 1/3. Mid and hind tibiae yellowish-brown with narrow, white patch latero-basally, darkened at distal about $1 / 4$. Fore tarsi not enlarged, but darkened. Mid and hind tarsi black except for each first-mere. Hind metatarsus narrow, parallel-sided, about 6 times as long as broad, pale yellow except distal $1 / 4$ black. Calcipala and pedisulcus well developed. All claws simple. Wing hyaline; basal section of radius haired; basal tufts brownish-yellow. Knob of haltere pale yellowish. Abdomen greyishbrown evenly clothed with golden hairs that are rather longer laterally; basal fringe yellow. Terminalia as in Fig. 3; ovipositor lobe forms pointed triangular process that is curled apically, covered with normal hairs. Genital fork spatulate at extreme base, with strongly arched arms, of which distal half curved subrectangularly against basal half; distal half of arm without any projection and widely attached with segment IX at distal end. Spermatheca spherical, with faint surface reticulation. Cercus rather small, about 2.5 times as broad as its length, subquadrate in profile; its posterior corners rounded. Anal lobe rather broad ventrally, heavily sclerotized, with broad, rounded simple flap.

Male. General body color brownish-black. Length : body about $2.15 \mathrm{~mm}$, wing about $2.00 \mathrm{~mm}$.

Frons and clypeus brownish-black with a few pale yellow hairs. Upper eye facets in about 22 rows. Occiput with long pile mixed with pale yellow and lightly grey hairs. Antenna as in female except two basal segments pale brown. Scutum brownishblack, with lightly grey pollinosity and short, recumbent, pale yellow pile; its pattern almost similar to that of female. Color of legs as in female except all femora darker; fore metatarsus not enlarged, about 6.5 times as long as maximum breadth. Genitalia as shown in Fig. 3. Style short, broad apically, produced beyond level of spinule insertion. Coxite broad, 1.2 times as long as maximum breadth; its hind inner corner produced beyond base of style, strongly sclerotized at apex. Body of ventral plate narrow basally, becoming rather broader and flatter distally, sparsely covered with a few minute bristles on distal one-third. Median sclerite broadly expanded apically. Paramere with a number of hooks.

Pupa. Length : body $2.95-3.20 \mathrm{~mm}$, respiratory organ $0.78-0.95 \mathrm{~mm}$.

Head and thorax with normal tubercles and fine trichomes. Respiratory organ consisting of five thick primary and a number of thin secondary filaments; ventral one the fist) of primaries shortest; following three primaries subequal in size; third one not forked; last one almost degenerate as in Fig. 3. Abdomen with normal complement of hooks, consisting of four hooks each side dorsally on segments III-IV, a pair of hooks each side ventrally on segments VI-VII and a minute simple hooklet each side ventrally on segment V. Dorsal spine comb on segments VI-IX absent. Cocoon shoe-shaped, with well formed neck.

Larva. Length about $4.80 \mathrm{~mm}$. General body color lightly greyish-brown.

Head capsule pale brown; cephalic apotome evenly pale brown; head spots positive but indistinct except antero-lateral ones distinguishable; side of head evenly pale brown except its hind margin strongly pigmented, with clear area surrounding eye spots; eye- 
brow inconspicuous. Postgenal cleft rather shallow and broad, subequal to postgenal bridge in length; its depth shorter than its maximum breadth. Hypostomium as in Fig. 3 , with 9 apical teeth ranging in substraight; median tooth slightly prominent, corner teeth blunt and intermediate teeth subequal in size. Hypostomial setae 4-5 in each row, diverging posteriorly from lateral margin of hypostomium. Antenna slender and longer than stalk of cephalic fan, slightly pigmented on segment I; proportional length of segments I-IV about $12: 15: 11: 1$; second annulation not present. Mandible of typical form, with inner marginal serration present; comb teeth long, subequal in length to one another. Maxillary palpus about 2.5 times as long as breadth at base. Cephalic fan about 30 rays. Thorax greyish-brown. Lateral plate of proleg obscure. Each abdominal segment lightly grey. Cuticle of posterior segment dorsally with a number of narrow, flattened scales as in Fig. 3. Ventral papillae absent. Rectal gill trifid; each lobe with several secondary lobules. Rectal scales present. Anal sclerite of usual type; posterior arm longer than anterior one, extending to about 20 th row of hooks. Posterior circulet consisting of $4-20$ hooks in $120-130$ rows.

Holotype. Female (reared) preserved in alcohol solution, Type NSMT-I-Dipt. No. 03834, National Science Museum, Tokyo, Japan.

Type locality. Dawa River crossing the road from Negele to Wachille, Sidamo Province, Ethiopia; pupa collected on Nov. 7, 1969, by K. Ogata and M. Takahashi.

Allotype. Male (reared) mounted on slides, Type, NSMT-I-Dipt. No. 03835, National Science Museum, Tokyo, same data.

Paratype I. Female (reared) mounted on slides, Type, NSMT-I-Dipt. No. 03836, National Science Museum, Tokyo, same data ; 3 pupae preserved in alcohol solution, Type NSMT-I-Dipt. No. 03837, National Science Museum, Tokyo, same data ; 1 larva mounted on slide, Type, NSMT-I-Dipt. No. 03838, National Science Museum, Tokyo, same station, on Dec. 28, 1972, collected by $\mathrm{K}$. Uemoto and Yemane M. (All of the specimens are kept in the National Science
Museum, Tokyo, Japan.)

Paratype II. 1 female (reared) mounted on slides, same data as series of holoand allotype; two pupae preserved in alcohol solution, same data as above female. (All of the specimens are kept in the Central Laboratory and Research Institute, Addis Ababa, Ethiopia.)

Records (Map 2).

Material examined. Pupae and adults reared from the pupae-Dawa River crossing the road between Negele and Wachille, Sidamo Province, 7-XI-1969, K. Ogata and M. Takahashi. Larvae-same place, 28XII-1972, K. Uemoto and Yemane M.

Remarks Adults of this species closely resembles to $S$. gibense n. sp., but is different from the latter in details of the genitalia. In the female, the spermatheca is not so ovate as in $S$. gibense and the stout hairs widened basally on the ovipositor lobe are absent. In the male, the shape of the style or the ventral plate are distinguishable from those of $S$. gibense. The pupa is easily differentiated from that of $S$. gibense by the central one of vertical primary filaments being simple. The larva, also, differs distinctly from that of $S$. gibense by the shallow postgenal cleft and the darker, anterior head spots.

Biological notes. During the period from the end of rainy to the beginning of dry season, this species was collected from the river swiftly running on the rocky bed and flowing through the dry steppe (altitude about $1,200 \mathrm{~m}$ ). The larvae and pupae attach to the leaves, twigs and limbs washed on the rocky ashores in company with those of $S$. bovis. Its biting behaviour is not known.

\section{Simulium (Metomphalus) jimmaense new species}

Female. The single specimen failed to emerge from the pupa was available.

General body color brownish-black to black. Length : body about $2.80 \mathrm{~mm}$, with about $2.75 \mathrm{~mm}$.

Head brownish-black; frons sparsely with moderately long grey hairs. Clypeus yellowish-brown, with short pale yellow hairs. Occiput densely covered with long, pale, greyish-yellow pile. Antenna 11-segmented, 
brown darker toward its base. Mandible with about 36 serrations. Blade of maxilla with about 12 inner and about 7 retrorse teeth. Maxillary palpus pale brown with black hairs; segment $\mathrm{V}$ about twice as long as segment III ; segment III long subellipsoid, becoming narrower apically. Sensory vesicle rather short, ellipsoid in shape, about half as long as its segment; neck short, arising from antero-dorsal surface of vesicle, directed vertically. Thorax blackish-brown to black; scutum faintly greyish pollinose, showing rather indistinct pattern consisting of 3 narrow, dark stripes, rather sparsely covered with short, recumbent, pale yellow pile that is longer anteriorly; scutellum blackishbrown with long, pale yellow and greyish hairs. Pleural membrane, katepisternum and pronotum bare. All femora yellowishbrown, slightly darker distally. Fore tibia lightly yellowish-brown, with darker in distal 1/3. Mid and hind tibiae lightly yellowish-brown, darkened at basal and distal 1/4. Fore tarsi not enlarged, darkened. Mid and hind tarsi all darkened except for each first-mere. Hind metatarsus narrow, parallel-sided, about 6.5 times as long as broad, pale yellow except basal and distal 1/5 darkened. Calcipara and pedisulcus well developed. All claws simple. Wing hyaline; basal section of radius haired; basal tufts yellowish-brown. Knob of haltere pale yellowish. Abdomen brownish-black, evenly clothed with dark brown hairs; basal fringe yellow. Terminalia as in Fig. 4; ovipositor lobe forms slender triangular process that is tapering and curled apically, covered with normal hairs. Genital fork spatulate at extreme base, with very thin arms diverging widely from each other; arm with distinct shoulder medially and with two short, broad, chitinous processes projecting anteriorly and medially on its distal half. Spermatheca spherical, with faint surface reticulation. Cercus rather large, as long as broad, subtriangular in profile. Anal lobe rather broad ventrally, heavily sclerotized, with minute, simple flap.

Male. General body color brownish-black. Length : body $2.25-2.45 \mathrm{~mm}$, wing $2.05-2.30$ mm.

Frons and clypeus brown with a few pale yellow hairs. Upper eye facets in about 24 rows. Occiput with long pile mixed with pale yellow and lightly grey hairs. Antenna as in female except first flagellomere 1.5 times as long as the second. Scutum brownish-black with faint, white pollinosity, clothed with moderately long, recumbent, pale yellow hairs that are sparse medially; its pattern indistinct. Fore metatarsus not enlarged, about 6 times as long as maximum breadth. Abdomen blackish-brown, evenly clothed with rather long yellowish-brown hairs; basal fringe yellow. Genitalia as Fig. 4. Style tapering, slightly curved at apical one-third of its length, about two-thirds as long as coxite, with a minute spine at apex. Coxite rather slender, about 1.4 times as long as maximum breadth; its hind margin not produced beyond base of style. Basal arms of ventral plate broad; its body rather narrow, short; distal end truncated, with a minute, hairy process ventromedially. Median sclerite slender, not expanded apically. Paramere with numerous hooks.

Pupa. Length: body $2.85-3.40 \mathrm{~mm}$, respiratory organ $1.95-2.20 \mathrm{~mm}$. Head and thorax with normal tubercles and fine trichomes. Respiratory organ complex, consisting of 5 primary filaments and a number of secondary filaments as in Fig. 4; primary filaments rather slender, tapering; its basal arms short, running downward, one of them (the first) acute-angled against the adjacent one (the last). Abdomen with normal complement of hooks, consisting of four hooks each side dorsally on segments III-IV and a pair of hooks each side ventrally on segments VI-VII ; in addition, one minute hooklet each side ventrally on segment V. Dorsal spine comb on VI-IX absent. Cocoon shoeshaped, with well formed neck, loosely woven near anterior margin.

Larva. Not known.

Holotype. Male (reared) preserved in alcohol solution, Type NSMT-I-Dipt. No. 03839, National Science Museum, Tokyo, Japan.

Type locality. Little Gibe River Trib., running out from Hippopotamus Swamp near the east side of City of Jimma, Kafa Province, Ethiopia ; pupae collected on July 4, 1969, by K. Ogata and M. Takahashi. 
Allotype. Female (reared) mounted on slides, Type NSMT-I-Dipt. No. 03840, National Science Museum, Tokyo, same data.

Paratype. Male (reared) mounted on slides, Type NSMT-I-Dipt. No. 03841, National Science Museum, Tokyo, same data; 3 pupae preserved in alcohol solution, Type NSMTI-Dipt. No. 03842, National Science Museum, Tokyo, same data.

Remarks. Apparently, the adults of this species closely resemble to Simulium (Metomphalus) medusaeforme. Also, on the structural basis of the genitalia of both sexes, it is difficult to differentiate this species from $S$. medusaeforme, except that the former species have narrower body of ventral plate on the male. However, the pupal respiratory organ of general design is distinctly different from that of $S$. medusaeforme. In spite of the characters of the adults as mentioned above, we would place this species into the bovis-group until the larvae are obtained, according to the definition of the bovis-group by Crosskey (1969), that is, "Pupal abdomen unusual, lacking hooks or showing only one minute inconspicuous hooklet each side on segment 5 ".

Biological notes. The life history and behaviours of this species are not yet known, except that they breed in slow-running stream with about $5 \mathrm{~m}$ in width.

We are very grateful to Dr. D. J. Lewis, External Staff, Medical Research Council, British Museum (Natural History), London, for useful suggestions about Simulids of Ethiopian Region, and to Drs. Teffera Wonde, Getachew Bolodia and Assefa Tekle, former Directors, the Central Laboratory and Research Institute, Ethiopia, and Mr. M. Takahashi, Department of Medical Entomology, National Institute of Health, Japan, for giving supports to our surveys.

\section{REFERENCES}

Crosskey, R. W. (1960) : A taxonomic study of the larvae of West African Simuliidae (Diptera: Nematocera) with comments on the morphology of the larval black-fly head. Bull. Br. Mus. (Nat. Hist.) Entomol., 10 : 1-74.

Crosskey, R. W. (1969) : A re-classification of the Simuliidae (Diptera) of Africa and its islands. Bull. Br. Mus. (Nat. Hist.) Entomol. Suppl., 14 : 1-195.
Fain, A. and P. Elsen (1973): Notes sur les Simulies du Cameroun oriental (Diptera; Simuliidae). Rev. Zool. Bot. Afr., 87(3) : 519554.

Freeman, P. and P. de Meillon (1953): Simuliidae of the Ethiopian Region. London, $\mathrm{Br}$. Mus. (Nat. Hist.), 224 pp., British Museum, London.

Garms, R. and A. Post (1967): Die Simlium der Republik Guinea, Westafrica. Inst. Rev. Ges. Hydrobiol. Hydrogr., 52 : 1-36.

Garms, R. and W. Häusermann (1968) : Untersuchungen an Arten der Simulium alcockiGruppe aus Tansania, Ostafrika, und $\mathrm{Be}$ schreibung von zwei neuen Spezies. Rev. Zool. Bot. Afr., 78(1-2) : 64-80.

Gibbins, E. G. (1937) : Notes on Ethiopian Simuliidae, I. Ann. Trop. Med. Parasitol., 31 : 299-302.

Gibbins, E. G. (1937) : Simuliidae of the $\mathrm{Bu}^{-}$ ganda, Eastern and Western Provinces of Uganda. Bull. Entomol. Res., 28 : 289-309.

Gibbins, E. G. (1938) : Notes on Ethiopian Simuliidae, II. Ann. Trop. Med. Parasitol., 32 : 21-33.

Gibbins, E. G. (1939) : Simuliidae in Ruwenzori Expedition 1934-35. London, Br. Mus. (Nat. Hist.), $1: 11-27$.

Grenier, P. and M. Ovassa (1951): Simulies du Moyen Congo. Bull. Soc. Pathol. Exot., 44 : 222-234.

Grenier, P. (1956) : Contribution a l'etude des Dipteres vulnerants de l'Empire d'Ethiopie, II. Simuliidae. Simulies et Onchocercose. Bull. Soc. Pathol. Exot., 49 : 182-196.

Lewis, D. J. (1964) : On the Sumulium Bovis complex, (Diptera, Simuliidae). Ann. Mag. Nat. Hist., 13(7) : 449-455.

Lewis, D. J. (i964): On the Simulium medusaeforme complex (Dipt., Simuliidae). Entomol. Mon. Mag., 100 : 183-187.

Lewis, D. J. (1974) : Some Tanzanian Simuliidae (Diptera). Entomol. Mon. Mag., 110 : 41-50.

Lewis, D. J. and R. H. L. Disney (1970) : Some Simuliidae (Diptera) from West Cameroon. Proc. R. ent. Soc. London (B), 39(7-8) : 99 108.

Marini de Araújo Abreu, M. M. (1960) : Subsídio para o conhecimento da fauna Simulídica Angolana (Diptera: Simuliidae). Anais Inst. Med. Trop., 17 : 697-704.

Marini de Araújo Abreu, M. M. (1961) : Simulídeos angolanos (Diptera: Simuliidae). Anais Inst. Med. Trop., $18: 77-91$.

Roubaud, E. and P. Grenier (1943) : Simulies de l'Ouest African. Bull. Soc. Pathol. Exot., $36: 281-311$. 


\section{摘 要}

\section{エチオピアのブユ I. Simulium 属の}

4 新種と 3 末同定種について

1969 1973 年の期間，エチオピア中央衛生研究所と日 本海外技術協力事業団の支援の下に，エチオピア帝国に おいて，オンコセルカ症媒介ブユの分布を調查した。こ の調查の過程で見出された 4 新種し 3 未同定種の外部形 態をここに記載する.

Simulium (Pomeroyellum) awashense n. sp. は $S$. (P.) mcmahoni に類似するが，幼虫の頭部 cleft $の$ 形, 触角第 2 節の第 1 , 第 3 節に対する比長, 蛹の呼吸系の 分岐数, 今成虫の ventral plateの形等によって後者と 区別できる。

Simulium (Metomphalus) gibense n. sp. は $S .(M$. fragai に最も類似するが，成虫の中胸側膜部に毛が生
えている点と, 合成虫の外部生殖器の把握器と ventral plate の形が異なる点で区別が容易である. 本種は人吸 血性を有する。

Simulium (Metomphalus) dawaense n. sp. は $S$. (M.) gibense n. sp. に酷似するが，蛹の分岐数上す成 虫の ventral plateの形に, 明膫な差が認められる.

Simulium (Metomphalus) jimmaense n. sp. は $S$. (M.) medusaeforme に酷似するが，蛹の呼吸糸の配列 様式と今成虫の ventral plateの形には顕著な差が認め られる。

3 未同定種 ‘Ethiopian A', ‘Ethiopian B', および 'Ethiopian C'は，それぞれ，Simulium (Pomeroyellum) alcocki, S. (P.) reyeri, S. (P.) djallonense に酷 似している. 蛹や幼虫の形質についてはこれらと明瞭な 差が認められたが，占成虫が得られなかったので，末同 定種として, それぞれの蛹, 幼虫, または古成虫の形態 を略述する。 